\title{
The use of whey protein extract for manufacture of a whipped frozen dairy dessert
}

\author{
Olga Musina ${ }^{1,2}$, Ali Rashidinejad ${ }^{3 *}$, Predrag Putnik ${ }^{4 * *}$, Francisco J. \\ Barba $^{5}$, Alireza Abbaspourrad ${ }^{6}$, Ralf Greiner ${ }^{7}$, Shahin Roohinejad ${ }^{8,9}$
}

\begin{abstract}
'Siberian Research Institute of Cheese-Making, Department of Scientific Information Analyses, Barnaul, Russia; ${ }^{2}$ Altai State Technical University named after I.I. Polzunov, Food and Chemical Engineering, Institute for Biotechnology, Barnaul, Russia; ${ }^{3}$ Massey University, Massey Institute of Food Science and Technology, Palmerston North, New Zealand; ${ }^{4}$ University of Zagreb, Faculty of Food Technology and Biotechnology, Pierottijeva 6, 10000 Zagreb, Croatia; ${ }^{5}$ Universitat de València, Faculty of Pharmacy, Nutrition and Food Science Area, Preventive Medicine and Public Health, Food Science, Toxicology and Forensic Medicine Department, Avda. Vicent Andrés Estellés, s/n, 46100 Burjassot, València, Spain; ${ }^{6}$ Cornell University, Department of Food Science, Ithaca, NY 14853, United States; ${ }^{7}$ Federal Research Institute of Nutrition and Food, Department of Food Technology and Bioprocess Engineering, Max Rubner-Institut, Haid-und-Neu-Straße 9, 76131 Karlsruhe, Germany; ${ }^{8}$ Department of Food Science and Nutrition, St. Paul, MN, 55108, USA; ' University of Minnesota, Burn and Wound Healing Research Center, Division of Food and Nutrition, Shiraz University of Medical Sciences, Shiraz, Iran *Corresponding author/Dopisni autor: Phone: +64 (06) 356 9099;

E-mail: A.Rashidinejad@massey.ac.nz; **Phone: +385(1)4605-036; Email: pputnik@alumni.uconn.edu
\end{abstract}

\section{Abstract}

The aim of this work was to substantiate the use of whey protein extract (WPE), a by-product of dairy industry, combined with different berry purees in the formulation of a whipped frozen dairy dessert (WFDD). After freezing, the swelling ability of WPE decreased significantly while at higher temperatures of the dispersion medium, the degree of swelling increased. A mixture containing $55 \pm 2 \%$ WPE and $45 \pm 2 \%$ milk presented a homogeneous consistency while the further processing did not improve the structure of the mixture. Final formulations of WFDD containing different berry purees (i.e. $10 \%$ blackcurrant puree, $25 \%$ cherry puree, or $30 \%$ strawberry puree) were proposed for which the nutritional facts were calculated. Recommended shelf life of the developed desserts at $-18{ }^{\circ} \mathrm{C}$ is suggested to be 20 days. Regulatory requirements and recommendations for the production of WFDD in an industrial scale were also developed. Recommended shelf life of the developed desserts at $-18^{\circ} \mathrm{C}$ is suggested to be 20 days. In conclusion, a WFDD was developed using WPE as a by-product of dairy industry.

\section{Key words: whey protein extract, whipped frozen dairy dessert, berry puree, organoleptic properties, swelling degree}

\section{Introduction}

Whey, a secondary dairy raw material, is a by-product of cheese manufacture. Worldwide, resources of whey exceed 130 million tons. In devel- oped countries (e.g. USA, Canada, Germany, France, and Sweden), the dairy industry processes 60-95\% of whey while in countries such as Russia most of the whey is disposed as waste. Although in some countries the whey is concentrated and dried to 
obtain products such as whey protein concentrate (WPC), whey protein isolate (WPI), demineralized whey and whey with hydrolyzed lactose, etc., this is still a substantial problem in terms of waste management at the small scale. During cheese making process, the main milk components, including more than $90 \%$ of lactose and globular proteins and about $75 \%$ of minerals are transferred into whey (Nateghi et al., 2012a,b). On a dry matter basis, whey consist of $85 \%$ lactose, about $4.1 \%$ nitrogenous substances (including proteins), variable amounts of milk fat, and $9.6 \%$ minerals (Saron et al., 2007). Therefore, whey is a nutritious product and should not be wasted in any form.

As whey solids contain biologically active superior proteins, their incorporation into foods such as dairy desserts would result in higher protein content of such food products (Pandiyan et al., 2010). In recent years, whey proteins have become the most employed functional food proteins in food formulations like processed cheese (Musina et al., 2017), protein bars, pasta, desserts and meat products such as sausages (Gharibzahedi et al., 2018; Alfaifi and Stathopoulos, 2010a; Alfaifi and Stathopoulos, 2010b). In Russia, specifically, many small and medium-sized plants cannot afford high-tech processing (e.g. ultrafiltration, nanofiltration, electrodialysis, drying, etc.) for whey. Thus, they process whey by the simplest methods, e.g. thermo-acid coagulation. This method is described at Federal Standard - GOST R 53493-2009 as "Dairy Albumin" so the terms "albumin" or "dairy albumin" are officially used. However, technically speaking this product is an extract of all whey proteins (including albumin), so it is labeled as whey protein extract (WPE).

In regard to utilization of whey proteins in functional foods, whipped dairy products, which are very popular all around the world, could be a good choice for the several reasons. Firstly, whipped dairy products are dispersed systems saturated with gas bubbles, distributed throughout the volume and are separated by thin, quite stable, and mechanically strong films of liquid. These films form a relatively rigid frame, which gives the foam a certain property. Obtaining a whipped structure requires the presence of certain concentration of surfactants, which can be proteins. Having excellent emulsifier properties, whey proteins are good surfactants to be used in whipped dairy product industry to create strong films of liquid in the whipped structure (Gharibzahedi et al., 2019). Secondly, whey proteins have a high foaming ability so the use of these proteins contributes to the increase in the viscosity of frozen whipped desserts. Correspondingly, the viscosity of the desserts influences the organoleptic characteristics as well as the distribution and retention of ice crystals and air bubbles in the product (Rybak, 2014). Thirdly, the presence of the fat in the formulation of whipped frozen desserts can increase the overrun of the dessert. Thus, whey proteins can be a good basis for whipped frozen desserts (WFDs). However, the functional behavior of processed whey in foams and emulsions may not meet the consumer expectations, if heated at temperatures higher than $70{ }^{\circ} \mathrm{C}$, which is traditionally used for whey processing. Heat treatment of whey at temperature higher than $70^{\circ} \mathrm{C}$ results in impairment of foaming properties (Lim et al., 2008). Nevertheless, in the case of WPI, it was discovered that once heated for $1 \mathrm{~min}$ at $70^{\circ} \mathrm{C}$, it achieved a better foaming ability and improved foaming stability than the rest of the protein samples (Alfaifi and Stathopoulos, 2010a; Alfaifi and Stathopoulos, 2010b; Zhu and Damodaran, 1994). This progress in foaming properties results from not only conformational transformation but also from the proportion between monomeric and polymeric protein species found in WPI. The outcomes established that while monomeric proteins facilitated foamability, polymeric proteins supported foam stability (Alfaifi and Stathopoulos, 2010a; Alfaifi and Stathopoulos, 2010b; Zhu and Damodaran, 1994). Alpha-lactalbumin, the major whey protein, has a good potential as a blowing agent.

Giri et al. (2012) reported that replacement of milk solids-not-fat (SNF) with whey resulted in an organoleptically acceptable frozen product, which was almost similar to the untreated frozen desserts. Effect of WPC, as a partial substitution of milk SNF, in ice cream formula was also investigated by El-Zeini et al. (2016) and it was found that increasing whey protein concentrate decreased hardness, cohesiveness, gumminess, and chewiness in texture profile analysis, while there were increases in adhesiveness and springiness in the fresh ice cream. Dried whey could be used to replace 30-40 \% of milk SNF without affecting the organoleptic qual- 
ity of ice cream (Giri et al., 2012). WPC is used for replacing traditional additives like milk powder and egg albumin in ice cream and frozen beverages as well as other food products such as meat products, pasta, and processed cheese spread (Giri et al., 2012). The addition of whey solids in desserts, ice cream, and milk shake was found to increase the nutritional value of such products (El-Zeini et al., 2016; Giri et al., 2012; Pandiyan et al., 2012). WPC after high hydrostatic pressure modification was used for improving body and texture of low-fat ice cream (Lim et al., 2008), as well as improvement in flavor (Chauhan et al., 2010). Kulfi is an Indian frozen dairy product having almost identical composition as that of ice cream. Effect of incorporating whey protein concentrate into stevia-sweetened Kulfi on physicochemical and sensory properties was studied by Giri et al. (2012) who found an increase in WPC level resulted in decrease in freezing point, melting rate, hardness, moisture and protein percentage of the product. The reduced-fat and low-fat ice creams were prepared using $4 \%$ WPI as the fat replacement ingredient; both hardness and melting resistance increased significantly $(\mathrm{P}<0.05)$ using whey protein isolate in reduced-fat and low-fat ice creams (Akalın et al., 2007). Alfaifi and Stathopoulos (2010) indicated that it was possible to substitute egg yolk with WPC or sweet WPI in Gelato, a frozen Italian dessert that contains a minimal amount of whipped air, allowing for a cheaper product, without any detrimental change in physical quality parameters. Increasing WPC substitution led to an increased overrun, increased number of air cells formation, and improved texture characteristics of the Gelato samples (Alfaifi and Stathopoulos, 2010a).

The effect of two whey protein-based fat replacers, namely Dairy Lo and Simplesse, on the sensory properties of low-fat and non-fat chocolate ice cream was also studied by Prindiville et al. (2000). Simplesse was more similar to milk fat than was Dairy Lo in its effect on brown color, cocoa flavor, cocoa character, and textural stability but was less similar in terms of thickness and mouth-coating. The effect of Simplesse on textural and sensory characteristics of low-fat vanilla ice cream was also studied in another study (Yilsay et al., 2005). Results emphasized the importance of the fat as a flavor modifier and the improvement of texture by addition of Simplesse. However, to date, whey proteins, specifically in form of WPE produced in Russia, have not been used in the formulation of WFDs and their effect on physicochemical and organoleptic characteristics, foam overrun and foam stability of these products have not been investigated yet.

Newly developed or modified products should cause little or no change in quality and they should be as appetizing as traditional foods (Stampanoni Koeferli et al., 1996). Thus, to avoid the undesirable effects of WPE on the organoleptic characteristics of the developed dessert and introducing desirable flavors in the current study, we decided to add three different berry purees. Berries are rich source of antioxidants such as polyphenols (Bursać Kovačević et al., 2016a; Bursać Kovačević et al., 2016b; Bursać Kovačević et al., 2015). In addition, they contain substances (in particular pectin) which can positively affect foam stability and consistency of the dessert. Blackcurrant puree used in the current investigation had a high content of dry substances $(22 \pm 2 \%)$ and pectin, cherry puree contained $14 \pm 2 \%$ of dry substances and less pectin than blackcurrant puree, while strawberry puree had a low content of dry (10 $\pm 2 \%)$ and pectin substances. Since berries contain numerous health benefits (Agustinah et al., 2016; Flores et al., 2013; Khanal et al., 2012), adding berry purees to the dessert would increase the nutritional value of the dessert. Thus, the aim of this study was to examine the use of WPE in the formulation of WPDs in order to develop a functional dairy product in which a significant amount of WPE could be used. In addition, the influence of the type and the concentration of berry puree (as flavoring agents) on organoleptic characteristics, foam overrun, and foam stability were investigated. After all, recipes and technology of whipped frozen dairy dessert was developed and the shelf life of the developed dessert product was studied.

\section{Materials and methods}

\section{Materials}

WPE was granted by Lakt Co. (Barnaul, Russia). Milk and cream were obtained from the same company. The protein extract was manufactured 
in accordance with the Russian standard GOST R 53493 'Dairy albumin Specifications'. Four types of commercial stabilizers were also investigated:

/ High-esterified Citrus Pectin Classic CS 534, standardized by glucose (Herbstreith \& Fox KG Pektin-Fabriken, Germany);

/ Supergel 1000 (JSC “Belstar-Plus”, Russia);

/ Turrisin RM 4 (BK Giulini GmbH, Germany); and

/ Denice 805 R (Rikevita SDN. BHD., Malaysia).

Sugar (sucrose) was purchased from a local supermarket (Barnaul, Russia). Blackcurrant, cherry, or strawberries purees (frozen or fresh) were obtained from a "Fruit Paradise" (Barnaul, Russia).

\section{Whipped frozen dairy dessert (WFDD) manufacture}

The full technological process of manufacturing the WFDD is summarized in Figure 1. Firstly, the analysis of the incoming raw materials was carried out. All raw materials met the national quality standards (e.g. TR TS 033/2013, GOST R 53435, GOST 21-94, GOST 22371-77). It is notable that this scheme (Figure 1) also includes the description of WPE preparing although in our experiments we used ready-made commercial WPE. Technically, WPE is made from whey by thermo-acid coagulation method described at Russian Federal Standard-GOST R 53493-2009 and then is frozen to $-18{ }^{\circ} \mathrm{C}$. Before making WFDD in the current experiment, the frozen WPE was defrosted and swelled in warm milk. Thereafter, the milk-WPE mix was put into a rotary-pulsation apparatus (Fryazino, Russia), where it was treated to a homogeneous consistency for approximately 15 min. To obtain the right dessert mixture in a bath, firstly, the liquid products (milk-WPE mixture, cream, and berry puree) were poured before the dry products (sugar and stabilizer) were added. For rapid dissolution and stability, the stabilizer was introduced into a small amount of warm cream. After adding the stabilizer, the mixture was filtered (woven grid, stainless steel, mesh size 1-2 mm, A1-OShF, Ural Electrochemical, Novouralsk, Russia) and pasteurised at $80-85^{\circ} \mathrm{C}$ for 50-60 s. Thereafter, the mixture was cooled and filtered again with the same filter.

The filter media was periodically cleaned or replaced to avoid large amounts of sediment. The manufactured mixture was cooled to $6 \pm 2{ }^{\circ} \mathrm{C}$ and ripened at this temperature for about 4 hours. The final product (WFDD) was then made using an ice cream maker (Nemox Gelato Harlequin 1.1; Nemox S.p.A., Italy) containing a 1.1 liter stationary bowl and rotating beaters (32 rpm for $20 \mathrm{~min}$ ). The whipping was performed at $6 \pm 2{ }^{\circ} \mathrm{C}$ while the temperature of the bowl was $-18^{\circ} \mathrm{C}$. The product was then quenched in a freezer at $-18{ }^{\circ} \mathrm{C}$ for 30 min. Finally, WFDD was packed and labeled concerning the technical regulations of the Eurasian Economic Union TR TS 005/2011. The final product specifications of the WFDD with berry fillers manufactured in the current experiment are presented in Table 1.

TABLE 1. Formulation of whipped frozen dairy dessert (1000 kg)

\begin{tabular}{l|l|l|l}
\hline \multirow{2}{*}{ Ingredients } & Raw materials, $\mathrm{kg}$ & \multicolumn{2}{l}{} \\
\cline { 2 - 4 } & With blackcurrant & With cherry & With strawberry \\
\hline Milk (2.5\% fat content) & 195 & 162 & 150 \\
\hline WPE & 240 & 198 & 185 \\
\hline Cream (30 \% fat content) & 435 & 360 & 335 \\
\hline Sugar (sucrose) & 27.5 & 27.5 & 27.5 \\
\hline Stabilizer Denice 805 R & 2.5 & 2.5 & 2.5 \\
\hline Blackcurrant puree & 100 & - & - \\
\hline Cherry puree & - & 250 & - \\
\hline Strawberry puree & - & - & 300 \\
\hline Total & 1000 & 1000 & 1000 \\
\hline
\end{tabular}




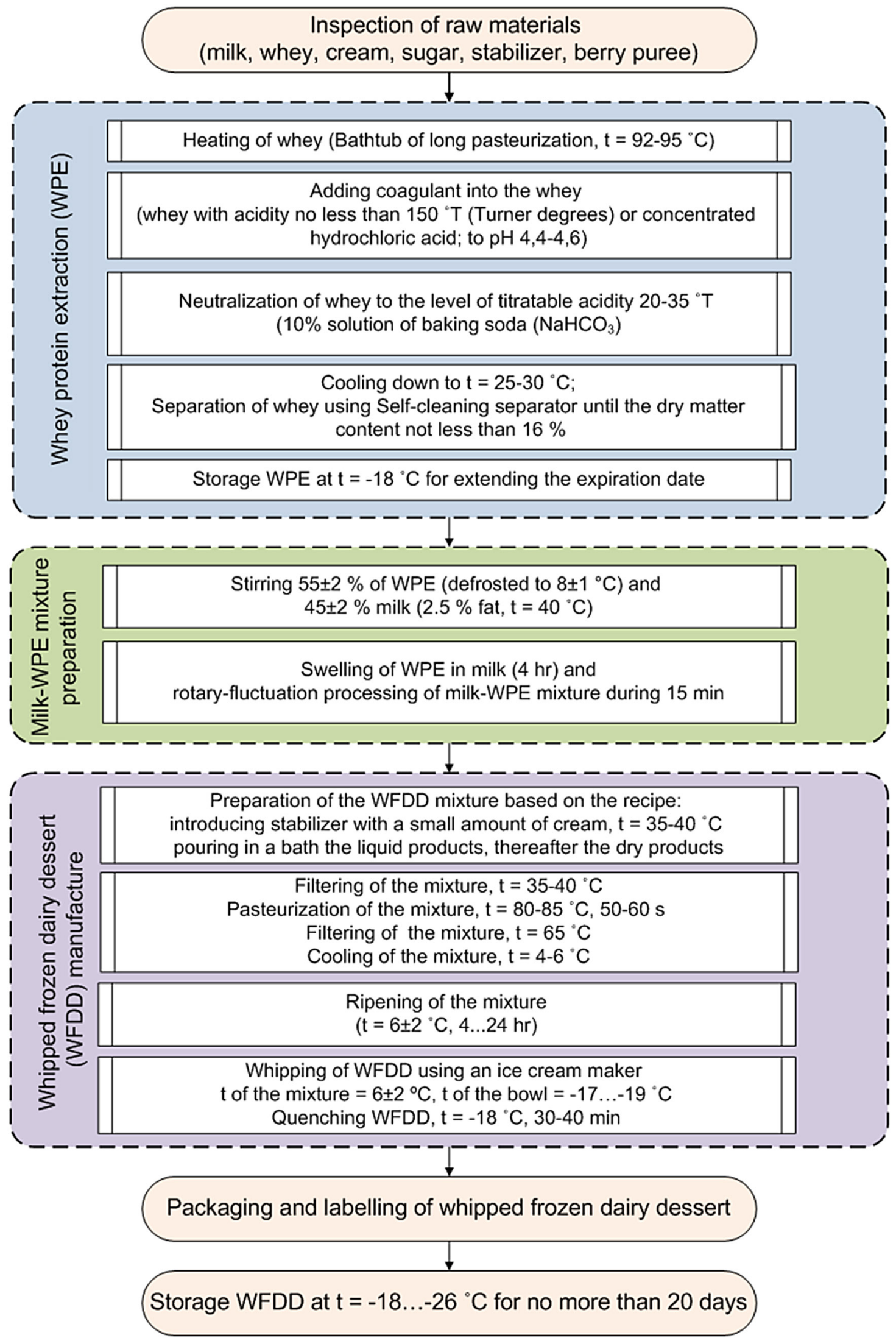

FIGURE 1. Flowchart of the technological process of manufacturing whipped frozen dairy dessert. WPE: whey protein extract, WFDD: whipped frozen dairy dessert 
Microstructure study of the milk-WPE mixture samples

Microstructure of milk-WPE mixture beside that of the WFDD was studied using a biological microscope (Microscopium, Mikromed-1, option 2-20, Ningbo Sheng Heng Optics \& Electronics Ltd., China) equipped with binocular visual head (Ningbo Sheng Heng Optics \& Electronics Ltd., China). The studies were conducted in transmitted light mode by the bright field method. The visual head of the microscope worked in conjunction with the video-ocular camera (Hangzhou Scopetek Opto-Electric Ltd., China). The images were processed using image manipulation software 'ScopePhoto' (Version x86, 3.1.475, Hangzhou Scopetek Opto-Electric Co., Ltd., China) at a magnification of 40 times.

\section{Measurement of swelling degree, foam overrun, and foam stability}

The swelling degree of WPE was determined as the mass difference before and after soaking in milk/cream using the method reported by Malysheva and Novakov (Malysheva and Novakov, 2011). An ice cream maker (Nemox Gelato Harlequin 1.1, Nemox S.p.A., Italy) with a 1.1 liter stationary bowl and rotating beaters (32 rpm) was used for foam formation. The mixture $(500 \mathrm{~mL})$ was whipped for $20 \mathrm{~min}$ and the whipping was performed at temperature of mixture $6 \pm 2{ }^{\circ} \mathrm{C}$ and at $-18{ }^{\circ} \mathrm{C}$ bowl temperature. Once the end point of whipping was reached, the foam overrun was measured. Air bubbles or foams contribute to a soft texture, light body of ice cream and retardation of ice cream melting (Sofjan and Hartel, 2004). The volume of air bubbles or foams in ice cream relates to the overrun which is normally reported in percentage (Marshall et al., 2003). For foam overrun measurement, foam and mixture were poured to a scaled cylinder. Foam overrun was calculated as the ratio of the final height of the foam $(\mathrm{mm})$ to initial height of the mixture $(\mathrm{mm})$ and expressed in percentage. Each measurement was replicated five times for each sample. This measurement was completed within 1-2 minutes after the foam was removed from the mixer. Foam stability experiment was carried out $24 \mathrm{~h}$ after freezing at $-18{ }^{\circ} \mathrm{C}$. For foam stability measurement, frozen foam and sample of initial mixture were poured into a scaled cylinder to measure total volume of foam, as the ratio of the initial height of the foam $(\mathrm{mm})$ to final height of the foam $(\mathrm{mm})$ and expressed in percentage. This process was repeated five times for each sample.

\section{Organoleptic evaluation of WFDD}

Organoleptic evaluation of frozen dairy dessert was perfomed immediately after removing the product from the freezer (in order to avoid melting) in accordance with the scale of the tasting evaluation. The product was dipped into individual serving cups immediately before evaluation. The experimental dessert samples were subjected to sensory evaluation by a panel of 12 panelists, who were staff members (with previous dairy products evaluation experience) of the Institute for Biotechnology, Food, and Chemical Engineering of Altai State Technical University, Russia under daylight in individual booths. The panelists were selected based on their availability and willingness to participate in the study. The maximum total score was 25 points, including 10 points for taste and smell (flavor), 10 points for consistency (body and texture), and 5 points for appearance and color. Panelists were also asked to note any defects or undesirable characteristics. The cups containing 1 scoop of frozen dairy desserts (about $25 \mathrm{~g}$ ) were labeled with random 3-digit codes generated randomly using Microsoft Excel 2010 (Microsoft Corp., USA, Redmond, Washington). Panelists were instructed to rinse their mouths before each sample and to expectorate water and sample. Water was provided for palate cleansing when panelists were in the booths. The order of presentation of the frozen dairy desserts was randomized across panelists to prevent bias effects. The scale used for evaluation by panelists was a $100 \%$-scale as follows: Like extremely - $100 \%$ of maximum score of a sensory parameter (for example, for consistency - 10 points); Like very much - 80; Like moderately - 70; Like slightly - 60; Neither like nor dislike - 50; Dislike slightly - 40; Dislike moderately - 30; Dislike very much - 20; and Dislike extremely - 10. The statistical analysis of the data (5 replications) was carried out using completely randomized design. 
Microbiological studies of WFDD

The total bacterial load of the WFDD was deterimend by a KMAFAnM cultural medium (KMAFAnM State research Center for applied Microbiology and biotechnology, Obolensk, Moscow region, Russia) designed to detect the total number of mesophilic aerobic and facultative anaerobic microorganisms. Briefly, $50 \pm 5 \mathrm{~g}$ of the commercial dry cultural medium was placed into $1000 \pm 50 \mathrm{~cm}^{3}$ of cold water. The mixture was then stirred, boiled for 3-5 min, and filtered through cotton-gauze filter. In the resulting cultural medium, active acidity was tested and adjusted to $\mathrm{pH}=7.3$ by adding lactic acid solution (20\%). Cultural medium brought to boiling again, poured into flasks, closed with cotton plugs, and sterilized at a temperature of $121 \pm 2{ }^{\circ} \mathrm{C}$ for $15 \pm 1$ min. The prepared cultural medium was tested for sterility. No change in the cultural medium after incubation at $30 \pm 1^{\circ} \mathrm{C}$ for $72 \mathrm{~h}$ was observed, which is an evidence of sterility of the medium. Directly before usage, cultural medium was melted in a water bath. The molten medium cooled to $40-45^{\circ} \mathrm{C}$ to avoid foaming. Cultural medium put in a Petri dish in the quantity necessary to create a layer of medium of at least $2 \mathrm{~mm}$. The cultivation modes were at $30 \pm 7^{\circ} \mathrm{C}$ and duration of $72 \mathrm{~h}$. The appearance of the visible colonies of microorganisms on a cultural medium was judged according to the number of the colonies observed.

The yeast or mold contamination of the WFDD was determined by a Saburo № 2 GRM cultural medium (State research Center for applied Microbiology and biotechnology, Obolensk, Moscow region, Russia). The cultural medium Saburo № 2 GRM is designed to detect the total number of yeast and mold fungi in milk and dairy products. Commercial dry cultural medium Saburo № 2 GRM in the amount of $70 \pm 1 \mathrm{~g}$ was introduced into $1 \mathrm{dm}^{3}$ of distilled water and left for 30 min for swelling. The medium was heated to melt the agar. In the resulting medium active acidity was tested and adjusted to $\mathrm{pH}=5.8$ using $20 \%$ lactic acid solution. Then the cultural medium was poured into flask and sterilized at $112 \pm 2{ }^{\circ} \mathrm{C}$ for $30 \mathrm{~min}$. Immediately before usage, the medium was melted in water bath, then added to $975 \mathrm{~cm}^{3}$ of culture medium containing $25 \mathrm{~cm}^{3}$ of antibiotic chloramphenicol solution and cooled to $46 \pm 1^{\circ} \mathrm{C}$ to increase the selectivity of the medium.
For preparation of chloramphenicol solution, $0.4 \mathrm{~g}$ of dry chloramphenicol was put into the $100 \mathrm{~cm}^{3}$ sterile volumetric flask, $10-20 \mathrm{~cm}^{3}$ of sterile distilled water at a temperature $35-40{ }^{\circ} \mathrm{C}$ was added stirred until dissolved, and then refilled with sterile distilled water to the mark $\left(100 \mathrm{~cm}^{3}\right)$. Mass concentration of streptomycin in solution was $4.0 \mathrm{~g} / \mathrm{dm}^{3}$.

\section{Model construction and data analysis}

The construction of mathematical models was carried out in 3D linear and non-linear surface fitting softwares TableCurve $3 D$ and TableCurve 2D (Systat Software Inc., USA, San Jose, California). Microsoft Excel 2010 (Microsoft Corp., USA, Redmond, Washington) was used for data calculation while the statistical data processing was carried out in accordance with the Russian standard GOST R 8.736-2011 (State system for ensuring the uniformity of measurements. Multiple direct measurements. Methods of measurement results processing. Main principles) at a significance level of $5 \%$. The means were compared for the significant differences using one-way ANOVA.

\section{Results and discussion}

\section{Nutritional composition of the manufactured WFDD containing WPE}

The nutritional composition of the produced WFDD containing WPE and different berry purees is presented in Table 2. The manufactured dessert containing between 5.6 to $7.1 \%$ protein was defined as better (more nutritious) choice compared to some other desserts on the market, such as ice cream products. Normally, the protein content of the regular ice cream is low (3.5-4.7 \%) (Pandiyan et al., 2012; Pandiyan et al., 2010; Akalın et al., 2007; El-Zeini et al., 2016). However, the protein content of ice cream and other frozen dairy desserts containing whey and whey products was reported to be relatively higher (between 5.0-8.0 \%) (Pandiyan et al., 2012; Pandiyan et al., 2010; Akalın et al., 2007; El-Zeini et al., 2016). In addition, since it contains 10 to $30 \%$ berry puree, this type of dessert would be a healthier choice as well. As mentioned earlier, there are positive effects derived from 
consumption of different berries (e.g. blackcurrant and strawberry) and cardiovascular problems, diabetes, cancer, etc (Agustinah et al., 2016; Flores et al., 2013; Khanal et al., 2012). Hence, there is a high interest in the food industry to replace a part of carbohydrates and fats in desserts and sweets with real fruit purees and extracts in order to manufacture healthier foods.

\section{The effect of temperature and time on swelling degree of WPE}

As WPE was used in developing the frozen dessert, it was necessary to study the effect of freezing and time of the exposure on its swelling degree. Swelling degree is an important characteristic taht affects the sensory properties and consistency of the frozen dairy desserts. The maximum swelling degree of $72 \%$ was observed in non-frozen WPE when the milk was held at $40{ }^{\circ} \mathrm{C}$ for 4 hours. When the duration of exposure was reduced to 20 minutes, the swelling degree decreased $(10.5 \%$ at temperature $6{ }^{\circ} \mathrm{C}$ and $14 \%$ at $40{ }^{\circ} \mathrm{C}$ ). After freezing, the maximum WPE swelling degree was $69 \%$ under the same conditions (temperature $40{ }^{\circ} \mathrm{C}$, duration of exposure 4 hours), which was $3 \%$ lower than before freezing. Upon exposure of 20 minutes, the swelling degree was $6 \%$ at $6{ }^{\circ} \mathrm{C}$ and $10 \%$ at $40{ }^{\circ} \mathrm{C}$. The maximum non-frozen WPE swelling degree at the temperature of $23^{\circ} \mathrm{C}$ was $65 \%$ with exposure for 4 hours in milk with $2.5 \%$ mass fraction of fat. By increasing the milk fat content, the swelling degree decreased. For the same duration

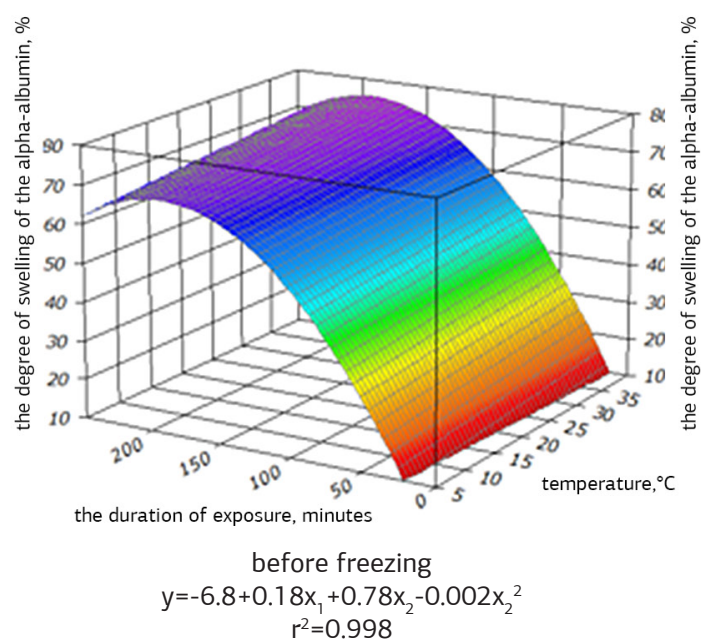

of WPE exposure at the temperature of $23^{\circ} \mathrm{C}$ in milk with $10 \%$ mass fraction of fat, the swelling degree was $52 \%$, which was $13 \%$ lower than that in milk containing $2.5 \%$ mass fraction of fat. After freezing, the WPE swelling degree with exposure for 4 hours in milk with $2.5 \%$ mass fraction of fat was $59 \%$, which was $6 \%$ lower than the same formulation before freezing. For the same duration of exposure, WPE in milk with $10 \%$ mass fraction of fat, the swelling degree was $50 \%$.

WPE swelling degree correlated with the temperature of the dispersion medium so that the swelling degree increased at higher temperatures. The duration of exposure greatly influenced the amount of the absorbed liquid. Apparently, the longer the duration of exposure, the higher the swelling degree of WPE. Increasing the mass fraction of fat in the milk reduced the WPE swelling degree. After freezing, the WPE swelling ability decreased. That reduction was mostly noticeable at low temperatures of the dispersion medium and at short exposure times. This might be due to the dehydration of the protein complex during freezing (Buaynov and Buaynova, 2016), which partially violated hydration connection, and as the result, WPE after freezing had less moisture. Thus, for dessert technology, it is preferable to avoid WPE freezing before the mixture formulation or the technological process should include a stage of milk-WPE mixture swelling. Since WPE swelling degree is slightly higher at a low mass fraction of fat in milk, the milk-WPE mixture should ripen before the cream is added.

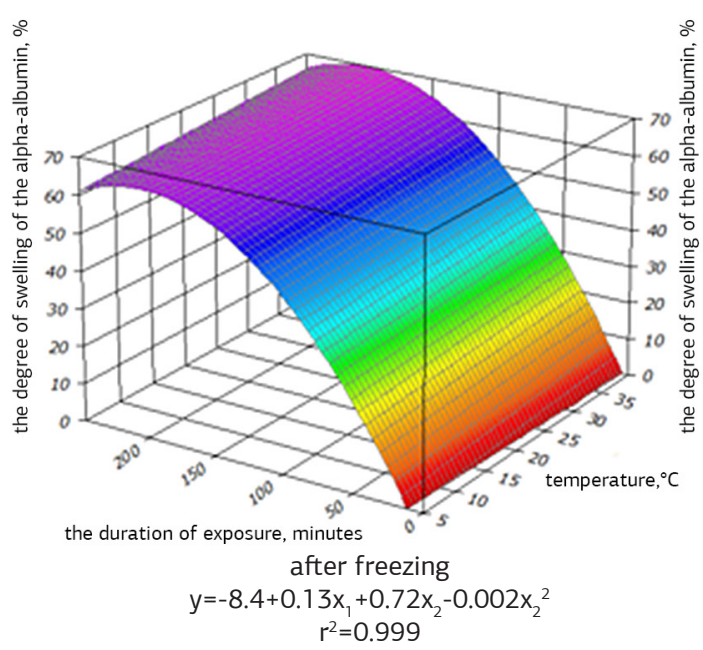

FIGURE 2. The dependence of the whey protein extract swelling degree on the temperature and duration of exposure 
TABLE 2. The nutritional and energy value of the whipped frozen dairy dessert per $100 \mathrm{~g}$

\begin{tabular}{l|l|l|l}
\hline \multirow{2}{*}{ Parameter } & \multicolumn{4}{l}{ Whipped frozen dairy dessert with: } \\
\cline { 2 - 4 } & Blackcurrant & Cherry & Strawberry \\
\hline Protein $(\mathrm{g})$ & 7.1 & 6 & 5.6 \\
\hline Fat $(\mathrm{g})$ & 14 & 12 & 11 \\
\hline Carbohydrates $(\mathrm{g})$ & 17 & 16 & 16.5 \\
\hline Energy value $(\mathrm{kcal} / \mathrm{kJ})$ & $222.4 / 930.5$ & $196 / 820.1$ & $187.4 / 784.1$ \\
\hline
\end{tabular}
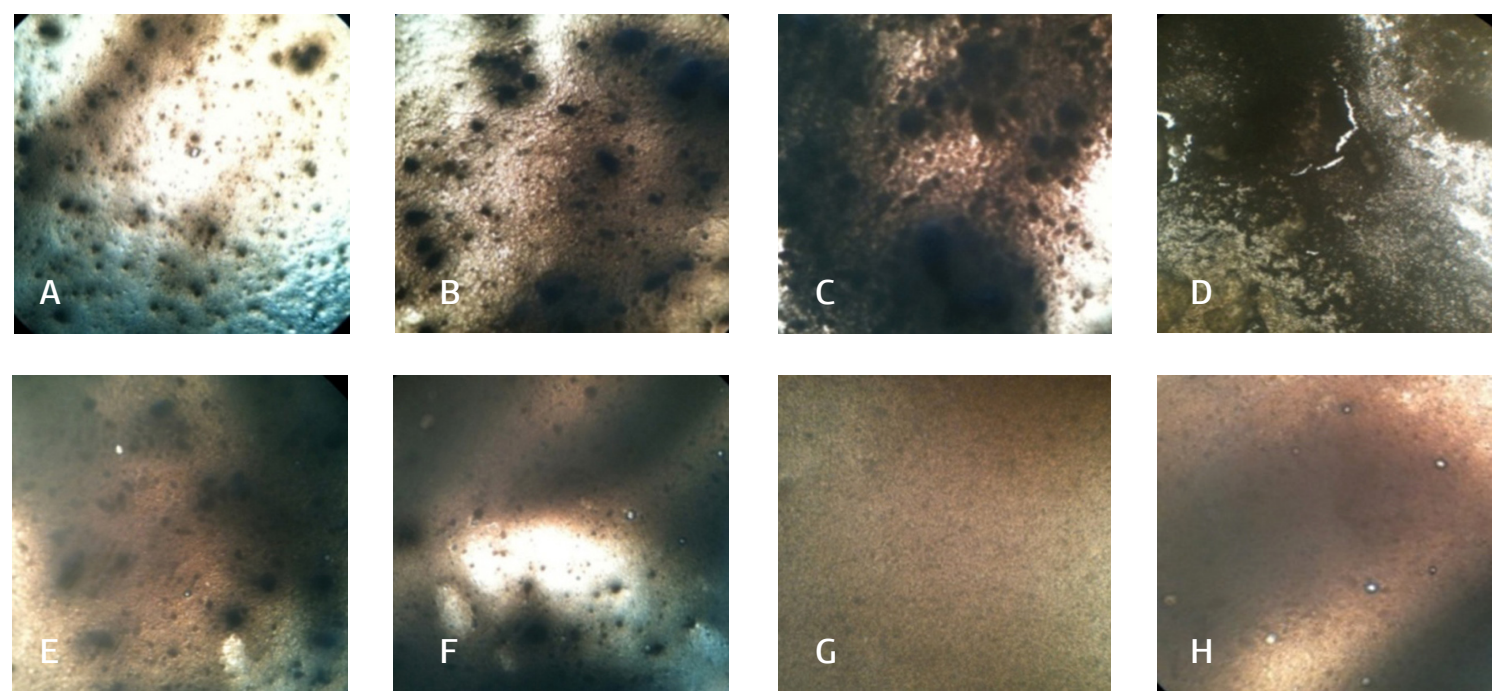

FIGURE 3. Microstructure of milk-whey protein extract mixture before $(A)$ and after $(B-H)$ treatment in rotary-pulsating apparatus.

The effect of rotary-pulsating on the microstructure of milk-WPE mixture

The microstructure of the milk-WPE mixture throughout the treatment process was studied every 2.5 minutes. Total treatment of mixture by rotary-pulsating apparatus lasted for 17.5 minutes. Micrographs of the microstructure of the milk-WPE mixture before treatment by rotary-pulsation apparatus (a) and during the treatment at each 2.5 minutes $(b-h)$ at 40-multiple increase are presented in Figure 3. Evaluation of WPE showed that WPE had a crumbly texture so it might be notable in the dessert without adversely affecting its organoleptic characteristics. To eliminate this property of consistency, treating of WPE in rotary-pulsating apparatus (Fryazino city, Russia) was proposed. Figure 3 shows that such a treatment had significant effect on the consistency of the mixture as it decreased the crumbliness of the mixture resulting in a more homogenous structure. Crumbly texture disappeared completely after 15 minutes of the treatment (Figure 3, G). At this stage, the milk-WPE mixture had a delicate homogeneous consistency and further processing did not have any additional influence on the structure of the mixture (Figure 3 , H).

These results indicated that the technology to produce the dessert should include pre-treatment of WPE mixture by rotary-pulsating apparatus for at least 15 min. For such a treatment, a mixture consisting $55 \pm 2 \%$ WPE $\left(8{ }^{\circ} \mathrm{C}\right)$ and $45 \pm 2 \%$ milk (2.5 \% fat) is suggested. The basic ingredients of the developed dessert in the current study were milk, WPE, sugar, and cream. In order to improve the mixture overrun and dessert consistency, we included stage of mixture ripening in the recipe. During ripening, milk proteins hydrate, milk fat becomes solid (because of the low temperature), the amount of bound water increases, and the amount 
of free water decreases. As a result, the WFDD had a delicate structure with small ice crystals. The WFDD obtained by this recipe had a creamy taste due to more fatty cream used. Results showed that when the concentration of WPE in the recipe was up to $15 \%$, the dessert had a very delicate consistency and the overrun disappeared easily while with a concentration of $25 \%$ or more of WPE in the recipe, the dessert had unpleasant light farinaceous taste with an undesirable light specific whey flavor and a slightly rough texture. Incorporation of more than $30 \%$ WPE in the dessert recipe resulted in an unpleasant farinaceous taste with a heavy undesirable specific whey flavor and a rough texture.
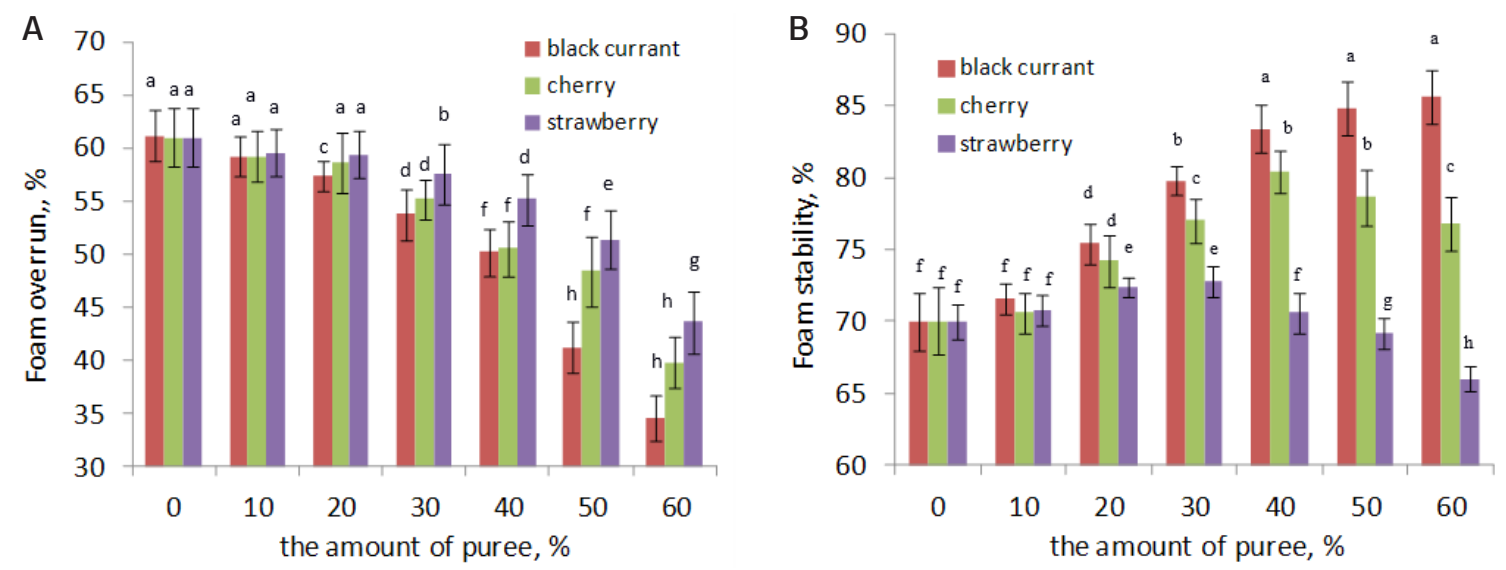

FIGURE 4. The dependence of foam overrun (A) and foam stability (B) on the type and concentration of berry puree. The columns with different superscripted letters are significantly different at $p<0.05$
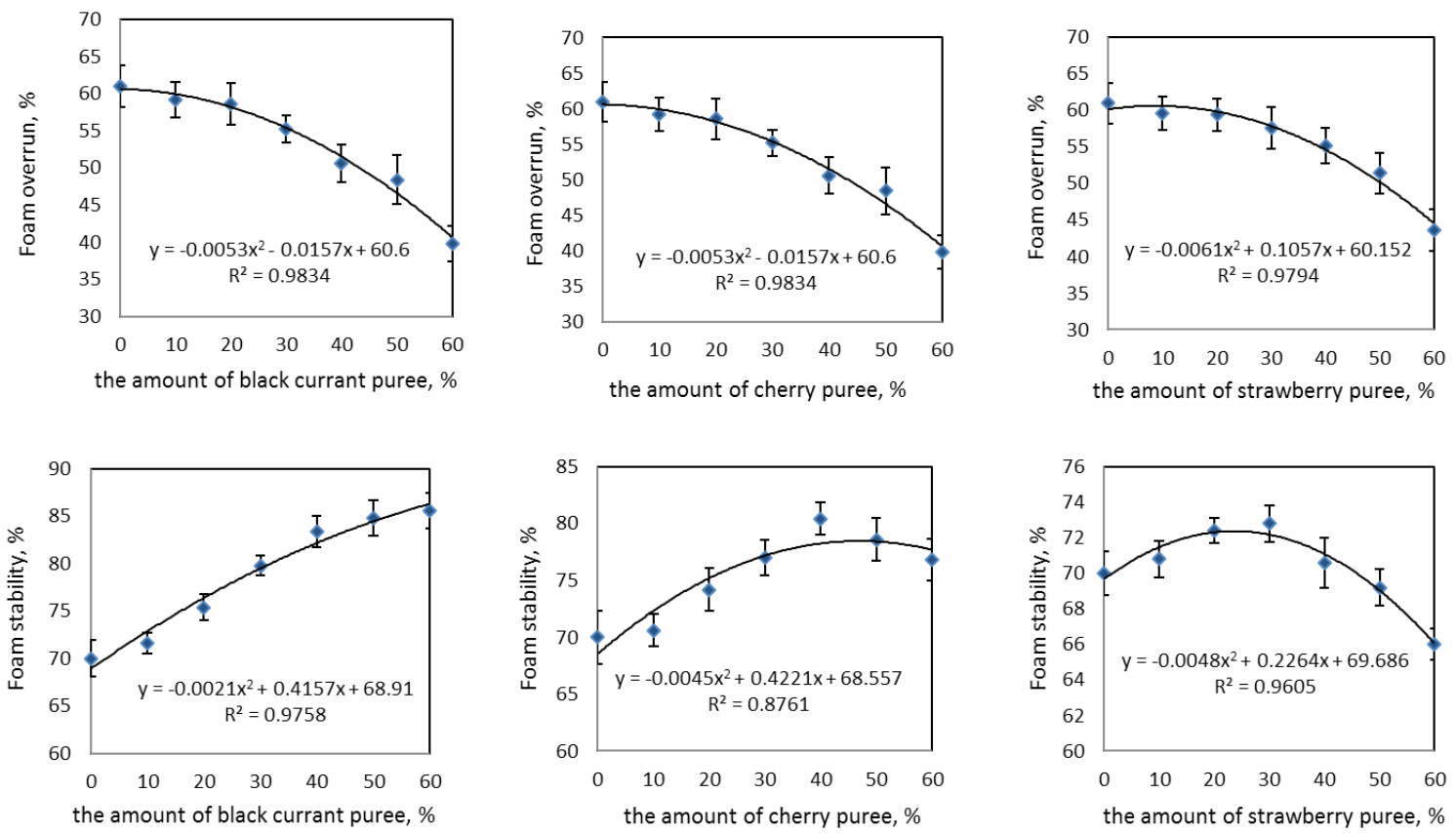

FIGURE 5. The influence of type and concentration of berry puree on the foam overrun and foam stability of the frozen dairy dessert 
The influence of type and concentration of the berry puree on foam overrun and foam stability in dessert mixtures

The dependence of the gas-liquid disperse systems overrun and stability from the type and concentration of berry puree are shown in Figures 4 and 5 . The largest foam occurred in samples with cherry or strawberry purees, but the formed foam quickly settled. Increase in concentration of any type of the berry purees lowered the foam overrun. Simultaneously, stability of such foam increased to a certain extent. Apparently, WPE and cream could result in a better foaming than the studied berry purees. Making the dessert with blackcurrant pu- ree gave a greater dispersed system stability compared to the desserts containing cherry or strawberry purees (Figure 5). Such findings might be due to the relatively high content of pectin in blackcurrants compared to cherry or strawberry. The most stable foam was achieved by adding $60 \%$ blackcurrant puree; however, such foam had minimal overrun. Foam stability with increasing concentrations of strawberry or cherry purees decreased more in comparison with increasing concentrations of blackcurrant puree, due to the moisture content in these types of puree (Figure 5). The berry puree containing more dry matter (blackcurrant puree) resulted in a more stable foam. Thus, the addition of up to $60 \%$ blackcurrant puree, up to $40 \%$ cherry

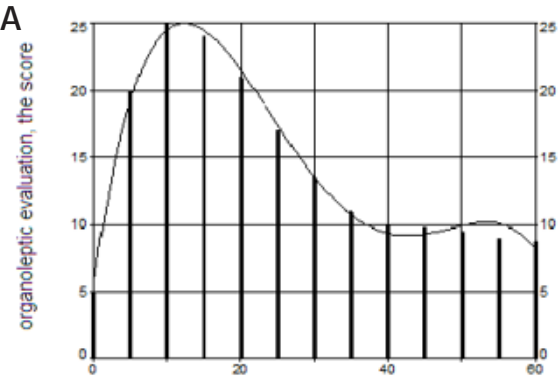

B

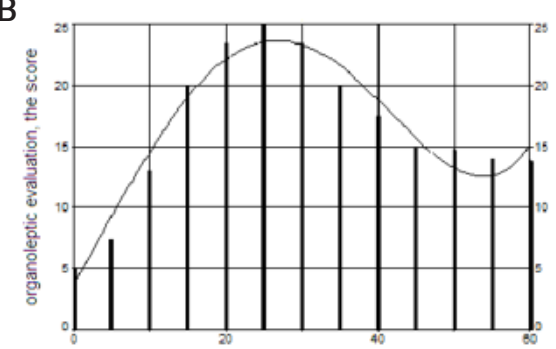

the amount of cherry puree, $\%$

\section{C}

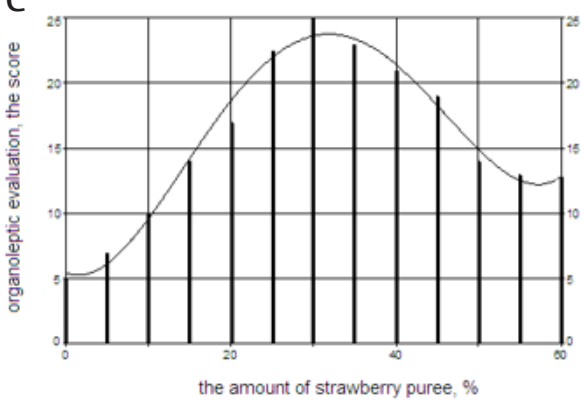

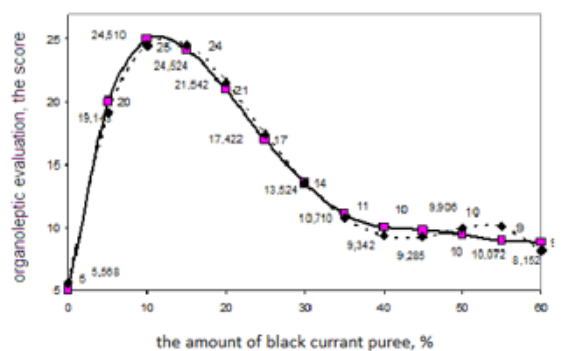
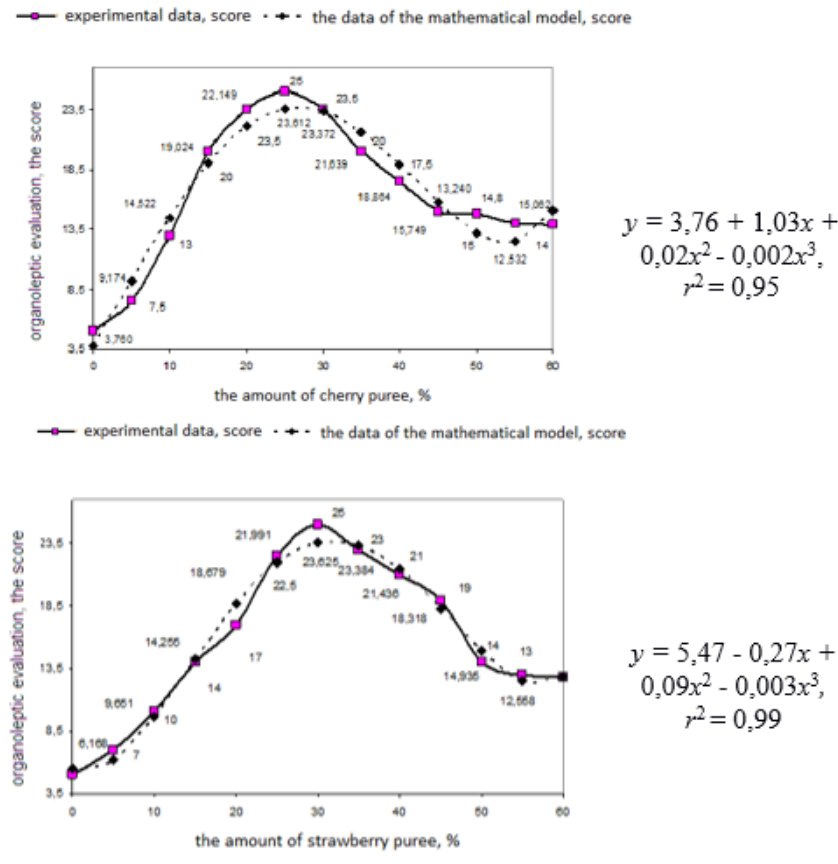

$\multimap$ experimental data, score $\cdots$ the data of the mathematical model, score
MATHEMATICAL MODEL

$y=5,57+3,75 x-$

$0,23 x^{2}+0,01 x^{3}$,

$r^{2}=0,99$

FIGURE 6. The influence of the berry puree concentration on the organoleptic characteristics (total 25-point score) of whipped frozen dairy dessert ( $A$, blackcurrant puree; $B$, cherry puree; $C$, strawberry puree) 
puree, or up to $30 \%$ strawberry puree enhanced the foam stability in the dessert mixture and had a positive effect on the dessert structure during storage.

The effect of type and concentration of puree on organoleptic characteristics of the WFDD

Organoleptic characteristics of WFDD studied in this experiment were; rating of taste, smell, consistency, appearance, and color. The maximum total score was 25 points, including 10 points for taste and smell, 10 points for consistency, and 5 points for appearance and color. The effect of different purees on this 25-point scale is shown in Figure 6 . In this series of experiments, concentration of puree increased with $5 \%$ and the corresponding mathematical models were created by software TableCurve 2D. The test showed a good convergence of model and experimental data. Highest organoleptic scores were given for WFDD containing 10 $\%$ blackcurrant puree, $25 \%$ cherry puree, or $30 \%$ strawberry puree. At such concentrations, the taste of the dessert was rich creamy-berry, without any detectable WPE taste, and the color was bright. At a lower concentration of the berry puree, the dessert had a special light taste of WPE. Higher berry puree concentrations gave the dessert a too-dark color although the taste was unusual for a dairy dessert (no milk taste but only the taste of berries). Thus, it was established that the formulation of the manufactured WFDD should include berry purees for a desirable taste and masking the unpleasant taste of WPE. These results are in agreement with the previous research where it has been reported that the incorporation of fruits (fruit juices, purees, or concentrates) into frozen dairy desserts can meet both the criteria of acceptable organoleptic characteristics and potential health benefits (Jridi et al., 2015; Soukoulis et al., 2014).

The effect of stabilizers on the foam overrun and foam stability as well as the organoleptic properties of the WFDD

Dairy food products which are whipped in order to add air bubbles into the products are known as complicated colloid systems (Thaiudom et al., 2008). Like other colloidal systems, foams are ther-
A

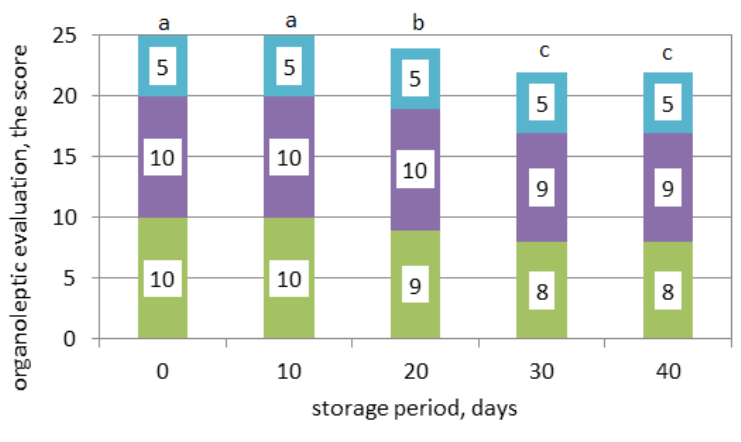

waste and smell $\quad$ consistency/texture appearance and color

B

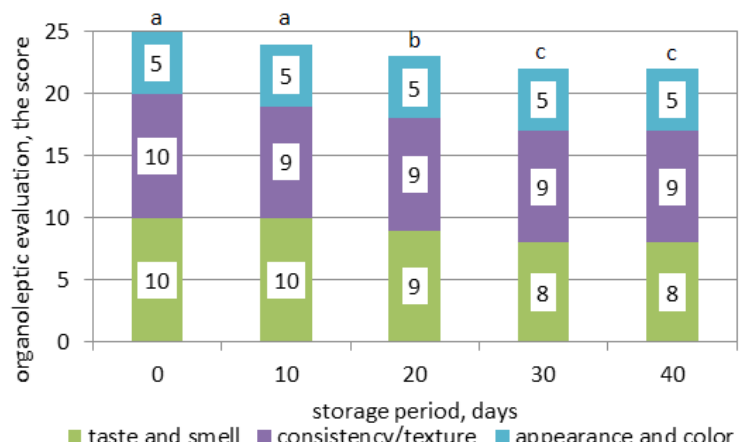

C

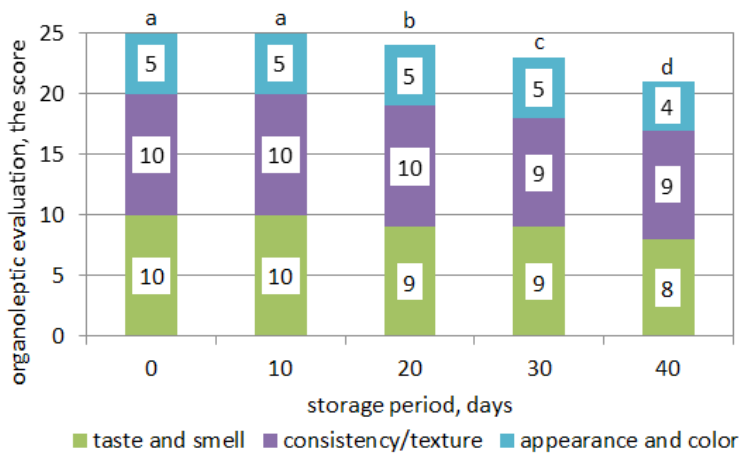

FIGURE 7. Change of organoleptic characteristics (total 25-point score) of whipped frozen dairy dessert with blackcurrant (A), cherry (B), and strawberry (C) during storage (40 days). The columns with different superscripted letters are significantly different at $\mathrm{p}<0.05$

modynamically unstable; i.e. the gas and the liquid, of which the foam consists of, tend to form two layers with a minimum phase separation surface (Olenev, 2002). Therefore, food foams are fixed by 
TABLE 3. The effect of the four different stabilizers on the organoleptic characteristics of the manufactured whipped frozen dairy desserts

\begin{tabular}{|c|c|c|c|c|c|c|}
\hline \multirow[t]{3}{*}{ Characteristic } & \multicolumn{6}{|l|}{ Stabilizers concentration, \% } \\
\hline & \multicolumn{6}{|l|}{ Citrus Pectin Classic CS 534} \\
\hline & 0 & 0.25 & 0.5 & 0.75 & \multicolumn{2}{|l|}{1.0} \\
\hline Consistency & \multicolumn{3}{|c|}{$\begin{array}{l}\text { Too dense, homogeneous, during storage forming } \\
\text { large ice crystals }\end{array}$} & \multicolumn{3}{|c|}{ A homogeneous, slightly astringent } \\
\hline Appearance & \multicolumn{6}{|c|}{ Matt surface with air bubbles } \\
\hline $\begin{array}{l}\text { Taste and } \\
\text { smell }\end{array}$ & \multicolumn{3}{|c|}{$\begin{array}{l}\text { Inherent to this type of dessert, without foreign } \\
\text { tastes and odors }\end{array}$} & \multicolumn{3}{|c|}{$\begin{array}{l}\text { Inherent to this dessert type, causes } \\
\text { slightly astringent mouthfeel }\end{array}$} \\
\hline \multirow[t]{3}{*}{ Colour } & \multicolumn{6}{|c|}{ Uniform throughout the mass, characteristic of the deposited berry puree } \\
\hline & \multicolumn{6}{|l|}{ Supergel 1000} \\
\hline & 0 & 0.25 & 0.5 & 0.75 & \multicolumn{2}{|l|}{1.0} \\
\hline Consistency & \multicolumn{2}{|c|}{$\begin{array}{l}\text { Too dense, homogeneous, during } \\
\text { storage forming large ice crystals }\end{array}$} & \multicolumn{2}{|c|}{ Homogeneous, less dense } & \multicolumn{2}{|c|}{$\begin{array}{l}\text { Homogeneous, friable, } \\
\text { soft, slightly viscous }\end{array}$} \\
\hline Appearance & \multicolumn{4}{|c|}{ Matt surface with air bubbles } & \multicolumn{2}{|c|}{$\begin{array}{l}\text { Glossy surface with air } \\
\text { bubbles }\end{array}$} \\
\hline $\begin{array}{l}\text { Taste and } \\
\text { smell }\end{array}$ & \multicolumn{6}{|c|}{ Inherent to this type of dessert, without foreign tastes and odors } \\
\hline \multirow[t]{3}{*}{ Colour } & \multicolumn{6}{|c|}{ Uniform throughout the mass, characteristic of the deposited berry puree } \\
\hline & \multicolumn{6}{|l|}{ Turrisin RM 4} \\
\hline & 0 & 0.25 & 0.5 & 0.75 & & 1.0 \\
\hline Consistency & \multicolumn{2}{|c|}{$\begin{array}{l}\text { Dense, homogeneous, during } \\
\text { storage forming large ice crystals }\end{array}$} & Homogeneous & \multicolumn{2}{|c|}{$\begin{array}{l}\text { Homogeneous, dense, } \\
\text { slightly viscous }\end{array}$} & $\begin{array}{l}\text { Thick, too } \\
\text { viscous, } \\
\text { rubbery }\end{array}$ \\
\hline Appearance & \multicolumn{3}{|c|}{ Matt surface with air bubbles } & \multicolumn{3}{|c|}{ Glossy surface with air bubbles } \\
\hline $\begin{array}{l}\text { Taste and } \\
\text { smell }\end{array}$ & \multicolumn{3}{|c|}{$\begin{array}{l}\text { Inherent to this type of dessert, without foreign } \\
\text { tastes and odors }\end{array}$} & \multicolumn{3}{|c|}{$\begin{array}{l}\text { Inherent to this dessert type, slippery } \\
\text { sensation in the mouth }\end{array}$} \\
\hline \multirow[t]{3}{*}{ Colour } & \multicolumn{6}{|c|}{ Uniform throughout the mass, characteristic of the deposited berry puree } \\
\hline & \multicolumn{6}{|l|}{ Denice $805 \mathrm{R}$} \\
\hline & 0 & 0.25 & 0.5 & \multicolumn{2}{|l|}{0.75} & 1.0 \\
\hline Consistency & $\begin{array}{l}\text { Dense, homogeneous, } \\
\text { during storage forming } \\
\text { large ice crystals }\end{array}$ & \multicolumn{2}{|c|}{$\begin{array}{l}\text { Homogeneous, smooth, } \\
\text { airy whipped }\end{array}$} & $\begin{array}{l}\text { Homogene } \\
\text { powdery a }\end{array}$ & $\begin{array}{l}\text { ous, airy whi } \\
\text { id lumpy }\end{array}$ & ed, light \\
\hline Appearance & Matt surface with air bu & bles & & & & \\
\hline $\begin{array}{l}\text { Taste and } \\
\text { smell }\end{array}$ & Inherent to this type of & essert, wi & thout foreign tas & tes and od & & \\
\hline Colour & Uniform throughout the & mass, cha & racteristic of the & deposited & erry puree & \\
\hline
\end{tabular}

heat treatment (e.g. dry marshmallows, cakes, ice creams), stabilized by tiny sugar crystal formation (nougat) or by adding foam stabilizers (Olenev, 2002). Higher overrun with many small air bubbles may cause a fluffy texture (Marshall et al., 2003). Large foaming can cause ice cream collapse (Dut- ta et al., 2004). To solve these problems and to stabilize the air bubbles, a number of studies have been undertaken employing stabilizers to inhibit or limit the movement of air bubbles (Thaiudom et al., 2008). Commonly used stabilizers in whipped products technology are gelatin, guar gum, pectins 
with different degree of esterification, food agar, agaroid, carrageenan, sodium alginate, sodium caseinate, xanthan gum, carob gum, modified gelling starch, potato or corn starch, wheat flour, soy proteins, methylcellulose, and furcellaran, or a mixture of these stabilizers (Olenev, 2002).

Although the ingredients used to manufacture the WFDD in the current study contributed to reasonable foam overrun and foam stability, it was found that their influence was not enough to keep the dessert structure stable during storage. The dessert had a too-dense and solid consistency even after storage at $-18^{\circ} \mathrm{C}$ for 24 hours while the dessert formed tangible large ice crystals after storage for 30 days, which may reduce the acceptability of the dessert. Therefore, it was decided to include stabilizers in the traditional dessert recipe. This technique would help stabilizing foam and fat emulsion, forming a smooth texture, slowing down ice crystals growth, and preventing structure destruction upon prolonged storage of the dessert. Stabilizers (pre-mixed with sugar) were added to the dessert composition in a range of $0.25 \%$ to $1 \%$ of the dessert mass. The effect of different stabilizers on the organoleptic properties of the dessert is presented in Table 3. Among the four stabilizers used in the current experiment (High-esterified Citrus Pectin Classic CS 534, Supergel 1000, Denice 805 R, and Turrisin RM 4), Denice 805 R at the concentration of $0.25 \%$ was found to be the best stabilizer for the WFDD. This stabilizer (Certifcate of state registration №U from 09.07.2008, additive for use in the food industry in the manufacture of ice cream, Malaysia), consists of a mixture of food emulsifiers (mono - and diglycerides of fatty acids E 471). Even at the lowest concentration of Denice $805 \mathrm{R}$ the dessert had a smooth, delicate, and airywhipped texture after 30 days of storage at $-18{ }^{\circ} \mathrm{C}$. With increasing stabilizer concentration, the dessert became less smooth (i.e. light powdery and lumpy texture). The foam overrun of blackcurrant, cheery, and strawberry desserts was $60.0 \pm 1.9 \%, 59.0 \pm 2.1 \%$, and $58.7 \pm 2.2 \%$, respectively. Foam stability after $24 \mathrm{~h}$ of storage at $-18^{\circ} \mathrm{C}$ was $75.2 \pm 2.4 \%, 74.7 \pm 1.9 \%$, and $72.7 \pm 2.3 \%$ for blackcurrant, cherry, and strawberry desserts, respectively. However, after 30 days of storage at the same temperature, the foam stability changed to $71.0 \pm 2.2 \%, 70.4 \pm 2.3 \%$, and $70.1 \pm 2.5 \%$ for blackcurrant, cherry, and strawberry desserts, respectively.
The effect of storage period on organoleptic properties of WFDD

Changes of organoleptic characteristics of desserts with different fillings during storage period are given in Figure 7. No significant changes in organoleptic characteristics of all dessert samples were observed up to 20 days, while on the $30^{\text {th }}$ day of the storage, an unpleasant smell was detected. This was also detectable for the samples tested on the $40^{\text {th }}$ day of storage (Figure 7$)$. The color remained unchanged for the samples with blackcurrant puree or cherry puree for the entire period of the storage, but the color of the sample with strawberry puree became weaker on day 40. The consistency of all the samples of dessert after 20 days of storage became slightly denser and after 35 days of the storage, the samples with cherry puree or strawberry puree began to form ice crystals, which were perceptible in the taste. Although not measured in this study, ice crystallization is also an important character in frozen desserts affected by stabilizer addition. BahramParvar and Goff (2013) used basil seed gum (BSG) at two concentrations (0.1 $\%$ or $0.2 \%)$ for ice cream stabilization. They measured the effect of this stabilizer on physical and structural properties (especially ice crystal size) and reported that BSG had no significant effect on ice crystal size after hardening; however, it reduced the ice recrystallization compared to commercial gums and no stabilizer. The rate of ice crystal growth was decreased by $30-40 \%$ due to the addition of BSG, compared to the commercially stabilized ice creams (BahramParvar and Goff, 2013).

\section{The effect of berry purees on microbial changes of the WFDD and its shelf life}

The data about mesophilic aerobic and facultative anaerobic microorganisms' quantity change are given in Figure 8. The number of mesophilic aerobic and facultative anaerobic microorganisms during 40 days of storage of dessert samples varied slightly and was the highest for the control dessert sample. Microbial colonies were visible as a thin coating on the cultural medium. The colonies had irregular shape with a creamy-slightly yellowish color. Profile of the colonies was bumpy and the size of them was in a range of 2 to $15 \mathrm{~mm}$. No yeast 
or mold colonies were observed during 30 days of storage. However, separate mold colonies (up to 3 $\mathrm{mm}$ in diameter) in the control dessert sample (neither WPE nor berry) were observed after 40 days.
The color of colonies was white and the shape was round with a smooth edge and a hilly profile. Thus, the recommended shelf life of the developed frozen dessert at $-18^{\circ} \mathrm{C}$ is expected to be not more than 20 days.

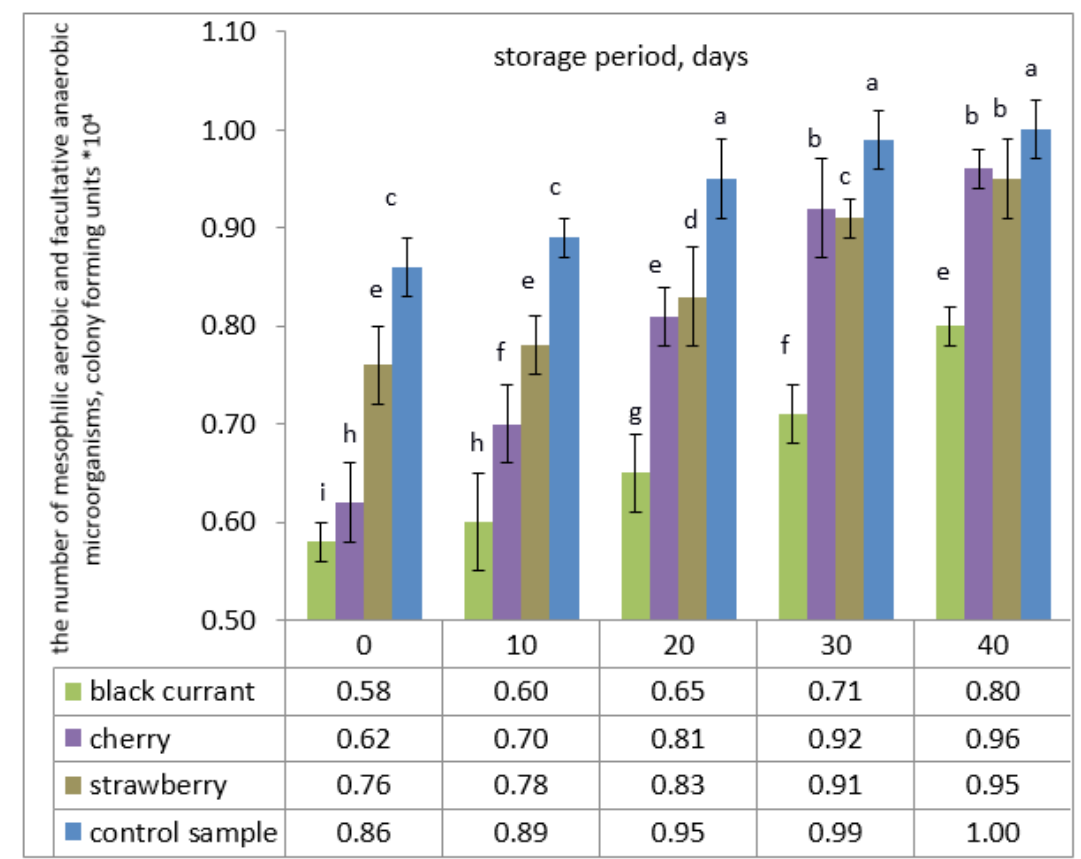

FIGURE 8. The change in the number of mesophilic aerobic and facultative anaerobic microorganisms (MAFAM) during storage of dessert samples at $-18{ }^{\circ} \mathrm{C}$ for 40 days. The columns with different superscripted letters are significantly different at $p<0.05$
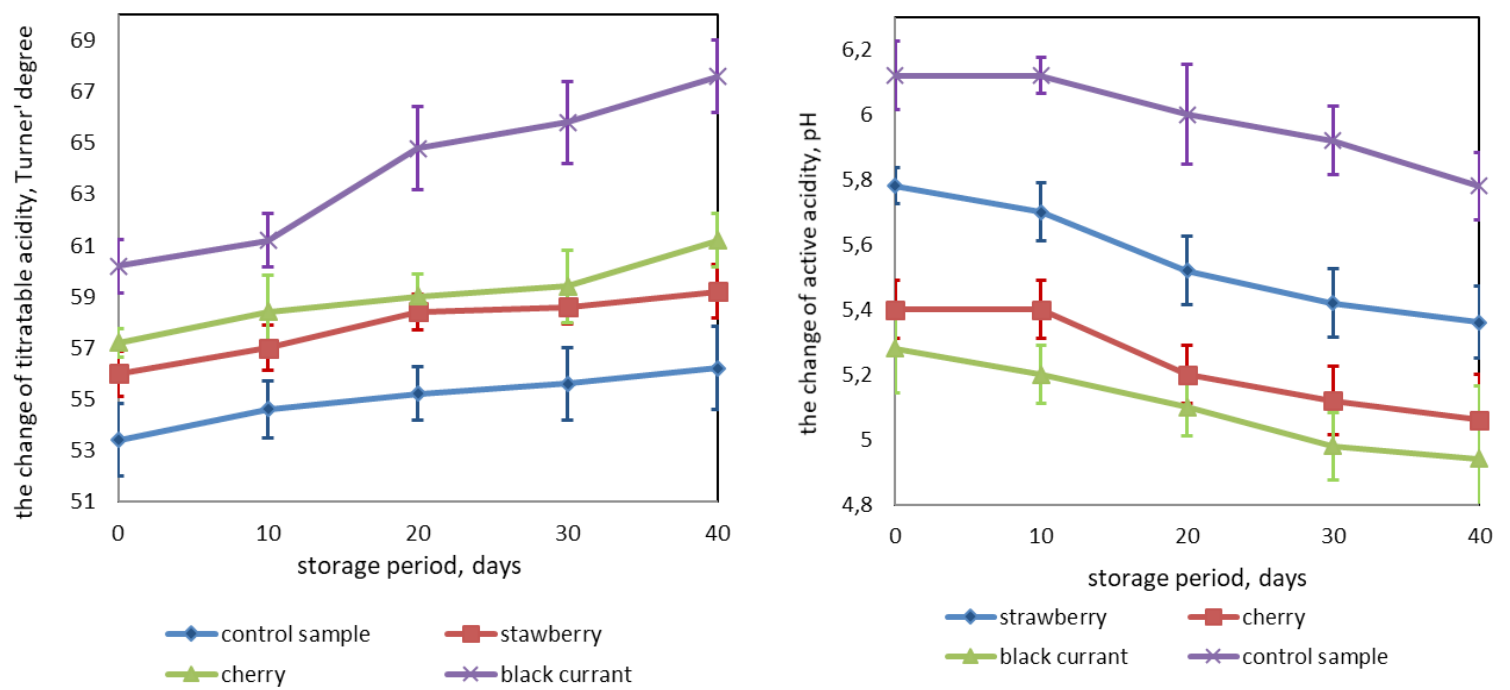

FIGURE 9. The changes in titratable acidity (top) and the active acidity (bottom) of different dessert samples during storage $\left(-18^{\circ} \mathrm{C}\right)$ 
The effect of berry purees on titratable and active acidity of the WFDD; specifications of the developed product

Changes in the titratable and active acidity of the dessert samples during storage were studied (Figure 9). According to the obtained data, titratable acidity in the samples within 40 days of storage grew, and active acidity decreased. However, these changes were not significant enough to impact on the organoleptic characteristics of the dessert. Regulatory requirements for WFDD developed; recommendations for the production of the dessert in an industrial environment are given in Table 4. Organoleptic and physicochemical parameters of WFDD must meet the specification requirements presented in this table.

TABLE 4. Recommended organoleptic (A) and physicochemical parameters (B; per $100 \mathrm{~g}$ ) of the whipped frozen dairy dessert

A

\begin{tabular}{|c|c|c|c|}
\hline \multirow[t]{2}{*}{ Parameter } & \multicolumn{3}{|c|}{ Characteristic of the dessert } \\
\hline & With blackcurrant & With cherry & With strawberry \\
\hline Taste and smell & \multicolumn{3}{|c|}{$\begin{array}{l}\text { Creamy, moderately sweet, slightly sour, without foreign tastes and odors, } \\
\text { with bright taste and smell of the respective berry filler }\end{array}$} \\
\hline Consistency & \multicolumn{3}{|c|}{ Gentle, homogeneous, without protein particles, with tiny parts of berries } \\
\hline Colour & $\begin{array}{l}\text { From pinkish-purple to } \\
\text { pale purple }\end{array}$ & $\begin{array}{l}\text { From pinkish-purple to } \\
\text { dark purple }\end{array}$ & light pink \\
\hline
\end{tabular}

B

\begin{tabular}{l|l}
\hline Parameter & Value \\
\hline Mass fraction of fat, \%, not less & 10 \\
\hline Mass fraction of dry substances, \%, not less & 30 \\
\hline Mass fraction of saccharose, \%, not less & 10 \\
\hline Titratable acidity, ${ }^{\circ} \mathrm{T}$, not more & 75 \\
\hline
\end{tabular}

\section{Conclusions}

This study focused on examining the utilization of whey in WFDD containing different types of berry puree and developed a new frozen dairy dessert product. As a preliminary study, the influence of freezing on the WPE swelling degree was also studied. It was observed that freezing could decrease the swelling ability of WPE. This was mostly noticeable at low temperatures and at short expositions. Conversely, the swelling degree of WPE increased at higher temperatures. Thus, WPE swelling degree correlated with the temperature of the dispersion medium. This indicates that in dessert manufacturing technology, it is preferable to avoid WPE freezing before preparation of the milk-WPE mixture or swelling time should be provided. In addition, the results showed that milkWPE mixture should ripen before the cream is added to the mixture. The concentration of WPE in the des- sert should not exceed 25\% because of the negative effects on organoleptic characteristics of the final product. It was also established that WFDD basic formulation should include one of the berry purees at specific concentrations; $10 \%$ blackcurrant puree, $25 \%$ cherry puree, or $30 \%$ strawberry puree. Denice $805 \mathrm{R}$ at a concentration of $0.25 \%$ was shown to be the best choice of stabilizer and resulted in a dessert with smooth, delicate, and desirable whipped texture even after storage for 30 days at $-18^{\circ} \mathrm{C}$. The foam was also stable during 30 days of storage at $-18^{\circ} \mathrm{C}$. Final formulations for the WFDD with blackcurrant, cherry, or strawberry were proposed and nutritional facts were calculated. The recommended shelf life for the manufactured dessert stored at temperatures below $-18{ }^{\circ} \mathrm{C}$ was estimated to 20 days. We also introduced the regulatory requirements for such a developed whipped frozen dessert at the industrial scale. 


\section{Primjena ekstrakta proteina sirutke u proizvodnji smrznutog mliječnog deserta}

\section{Sažetak}

Svrha ovog rada bila je ispitati mogućnost primjene kombinacije pirea bobičastog voća i ekstrakta proteina sirutke (WPE), inače nusproizvoda mljekarske industrije, u proizvodnji smrznutog mliječnog deserta (WFDD). Nakon smrzavanja, sposobnost bubrenja WPE značajno je pala, međutim pri višim temperaturama medija za raspršivanje sposobnost bubrenja ponovno je rasla. U pogledu konzistencije

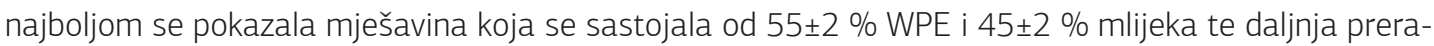
da nije rezultirala poboljšanjem teksture mješavine. Za konačne recepture WFDD s različitim udjelima pirea bobičastog voća (10 \% pirea crnog ribizla, $25 \%$ pirea višnje ili $30 \%$ pirea jagode) napravljeni su izračuni prehrambene vrijednosti. Preporučeni rok trajanja za proizvedene deserte iznosio je 20 dana na temperaturi čuvanja $-18^{\circ} \mathrm{C}$. Osim toga, uspostavljeni su zahtjevi sukladno zakonskim propisima kao i odgovarajuće preporuke za proizvodnju WFDD u industrijskom mjerilu. Zaključno, razvoj proizvodnje WFDD uključuje primjenu nusprizvoda mljekarske industrije - WPE.

\section{Ključne riječi: ekstrakt proteina sirutke, smrznuti mliječni desert, pire bobičastog voća, organoleptička svojstva, stupanj bubrenja}

\section{References}

1. Agustinah, W., Sarkar, D., Woods, F., Shetty, K. (2016): Apple and blueberry synergies for designing bioactive ingredients for the management of early stages of type 2 diabetes. Journal of Food Quality 39 (4), 370-382. https://doi.org/10.1111/jfq.12206

2. Akalın, A.S., Karagözlü, C., Ünal, G. (2007): Rheological properties of reduced-fat and low-fat ice cream containing whey protein isolate and inulin. European Food Research and Technology 227 (3), 889-895. https://doi.org/10.1007/s00217-007-0800-z

3. Alfaifi, M., Stathopoulos, C. (2010a): Effect of egg yolk substitution by sweet whey protein concentrate (wpc), on physical properties of gelato ice cream. International Food Research Journal 17, 787-793.

4. Alfaifi, M.S., Stathopoulos, C.E. (2010b): Effect of egg yolk substitution by sweet whey protein isolate on texture, stability and colour of gelato-style vanilla ice cream. International Journal of Dairy Technology 63 (4), 593-598. https://doi.org/10.1111/j.1471-0307.2010.00609.x

5. BahramParvar, M., Goff, H.D. (2013): Basil seed gum as a novel stabilizer for structure formation and reduction of ice recrystallization in ice cream. Dairy Science \& Technology 93 (3), 273-285.

https://doi.org/10.1007/s13594-013-0122-9

6. Buaynov, O.N., Buaynova, I.V. (2016): The physical and chemical changes of water and the hydration of the protein complex in cheese during freezing. Foods and Raw materials 4 (1), 13-18. https://doi.org/10.21179/2308-4057-2016-1-13-18
7. Bursać Kovačević, D., Gajdoš Kljusurić, J., Putnik, P., Vukušić, T., Herceg, Z., Dragović-Uzelac, V. (2016a): Stability of polyphenols in chokeberry juice treated with gas phase plasma. Food Chemistry 212, 323-331. https://doi.org/10.1016/j.foodchem.2016.05.192

8. Bursać Kovačević, D., Putnik, P., Dragović-Uzelac, V., Pedisić, S., Režek Jambrak, A., Herceg, Z. (2016b): Effects of cold atmospheric gas phase plasma on anthocyanins and color in pomegranate juice. Food Chemistry 190, 317-323. https://doi.org/10.1016/j.foodchem.2015.05.099

9. Bursać Kovačević, D., Putnik, P., Dragović-Uzelac, V., Vahčić, N., Babojelić, M.S., Levaj, B. (2015): Influences of organically and conventionally grown strawberry cultivars on anthocyanins content and color in purees and low-sugar jams. Food Chemistry 181, 94-100. https://doi.org/10.1016/j.foodchem.2015.02.063

10. Chauhan, J.M., Lim, S.Y., Powers, J.R., Ross, C.F., Clark, S. (2010): Short communication: Low-fat ice cream flavor not modified by high hydrostatic pressure treatment of whey protein concentrate. Journal of Dairy Science 93 (4), 1452-1458. https://doi.org/10.3168/jds.2009-2688

11. Dutta, A., Chengara, A., Nikolov, A.D., Wasan, D.T., Chen, K., Campbell, B. (2004): Destabilization of aerated food products: Effects of ostwald ripening and gas diffusion. Journal of Food Engineering 62 (2), 177-184. https://doi.org/10.1016/S0260-8774(03)00230-9

12. El-Zeini, H., El-Abd, M., Mostafa, A., El-Ghany, F. (2016): Effect of incorporating whey protein concentrate on chemical, rheological and textural properties of ice cream. Journal of Food Processing and Technology 7 (2). 
13. Flores, F.P., Singh, R.K., Kerr, W.L., Pegg, R.B., Kong, F. (2013): Antioxidant and enzyme inhibitory activities of blueberry anthocyanins prepared using different solvents. Journal of agricultural and food chemistry 61 (18), 4441-4447. https://doi.org/10.1021/jf400429f

14. Gharibzahedi, S.M.T., Koubaa, M., Barba, F.J., Greiner, R., George, S., Roohinejad, S. (2018): Recent advances in the application of microbial transglutaminase crosslinking in cheese and ice cream products: A review. International Journal of Biological Macromolecules 107, 2364-2374. https://doi.org/10.1016/j.ijbiomac.2017.10.115

15. Gharibzahedi, S.M.T., Hernández-Ortega, C., Welti-Chanes, J., Putnik, P., Barba, F.., Mallikarjunan, K, EscobedoAvellaneda, Z., Roohinejad, S. (2019): High pressure processing of food-grade emulsion systems: Antimicrobial activity, and effect on the physicochemical properties. Food Hydrocolloids 87, 307-320.

16. Giri, A., Rao, H.G.R., Ramesh, V. (2012): Effect of incorporating whey protein concentrate into steviasweetened kulfi on physicochemical and sensory properties. International Journal of Dairy Technology 66 (2), 286-290. https://doi.org/10.1111/1471-0307.12005

17. Jridi, M., Souissi, N., Salem, M.B., Ayadi, M.A., Nasri, M., Azabou, S. (2015): Tunisian date (phoenix dactylifera I.) by-products: Characterization and potential effects on sensory, textural and antioxidant properties of dairy desserts. Food Chemistry 188, 8-15. https://doi.org/10.1016/j.foodchem.2015.04.107

18. Khanal, R.C., Howard, L.R., Wilkes, S.E., Rogers, T.J., Prior, R.L. (2012): Effect of dietary blueberry pomace on selected metabolic factors associated with high fructose feeding in growing sprague-dawley rats. Journal of medicinal food 15 (9), 802-810. https://doi.org/10.1089/jmf.2011.0212

19. Lim, S.Y., Swanson, B.G., Ross, C.F., Clark, S. (2008): High hydrostatic pressure modification of whey protein concentrate for improved body and texture of lowfat ice cream. Journal of Dairy Science 91 (4), 1308-1316. https://doi.org/10.3168/jds.2007-0391

20. Malysheva, Z.N., Novakov, I.A. (2011): Surface phenomena and disperse systems: Izd-vo WolgSTU.

21. Marshall, R., Goff, H., Hartel, R. (2003): Ice cream. 6 td ed. New York.

22. Musina, O., Putnik, P., Koubaa, M., Barba, F.., Greiner, R., Granato, D., Roohinejad, S. (2017): Application of modern computer algebra systems in food formulations and development: A case study. Trends in Food Science $\odot$ Technology 64, 48-59.

23. Nateghi, L., Roohinejad, S., Totosaus, A., Mirhosseini, H., Shuhaimi, M., Meimandipour, A., ... Abd Manap, M.Y. (2012a): Optimization of textural properties and formulation of reduced fat Cheddar cheeses containing fat replacers. Journal of Food, Agriculture \& Environment 10 (2), 46-54.

24. Nateghi, L., Roohinejad, S., Totosaus, A., Rahmani, A., Tajabadi, N., Meimandipour, A., ... Abd Manap, M. (2012b): Physicochemical and textural properties of reduced fat Cheddar cheese formulated with xanthan gum and/ or sodium caseinate as fat replacers. Journal of Food, Agriculture \& Environment 10 (2), 59-63.
25. Olenev, Y.A. (2002): Raw materials for ice-cream production. Molochnaya Promyshlennost 7, 49-50.

26. Pandiyan, C., Annal Villi, R., Kumaresan, G., Murugan, B., Gopalakrishnamurthy, T. (2012): In vivo and in vitro effect of lactobacillus acidophilus in synbiotic ice cream enriched with whey protein concentrate. International Food Research Journal 19, 441-446.

27. Pandiyan, C., Kumaresan, G., Annal, V., Rajarajan, G. (2010): Incorporation of whey protein concentrates in ice cream. International Journal of Chemical Sciences 8, s563-s567.

28. Prindiville, E.A., Marshall, R.T., Heymann, H. (2000): Effect of milk fat, cocoa butter, and whey protein fat replacers on the sensory properties of lowfat and nonfat chocolate ice cream. Journal of Dairy Science 83 (10), 2216-2223. https://doi.org/10.3168/jds.S0022-0302(00)75105-8

29. Rybak, O. (2014): The role of milk proteins in the structure formation of dairy products. Ukrainian Food Journal 3, 350-360.

30. Saron, C., Lerayer, A.L.S., Sgarbieri, V.C. (2007): Use of bovine whey permeate and lactulose as potencial enhancers of the mrs and modified mrs media for the cultivation of species of probiotic bacteria. Brazilian Journal of Food Technology 10, 35-41.

31. Sofjan, R.P., Hartel, R.W. (2004): Effects of overrun on structural and physical characteristics of ice cream. International Dairy Journal 14 (3), 255-262. https://doi.org/10.1016/j.idairyj.2003.08.005

32. Soukoulis, C., Fisk, I.D., Bohn, T. (2014): Ice cream as a vehicle for incorporating health-promoting ingredients: Conceptualization and overview of quality and storage stability. Comprehensive Reviews in Food Science and Food Safety 13 (4), 627-655. https://doi.org/10.1111/1541-4337.12083

33. Stampanoni Koeferli, C.R., Piccinali, P., Sigrist, S. (1996): The influence of fat, sugar and non-fat milk solids on selected taste, flavor and texture parameters of a vanilla ice-cream. Food Quality and Preference 7 (2), 69-79. https://doi.org/10.1016/0950-3293(95)00038-0

34. Thaiudom, S., Singchan, K., Saeli, T. (2008): Comparison of commercial stabilizers with modified tapioca starches on foam stability and overrun of ice cream. Asian Journal of Food \& Agro-industry 1, 51-61.

35. Yilsay, T.Ö., Yilmaz, L., Bayizit, A.A. (2005): The effect of using a whey protein fat replacer on textural and sensory characteristics of low-fat vanilla ice cream. European Food Research and Technology 222 (1-2), 171-175. https://doi.org/10.1007/s00217-005-0018-x

36. Zhu, H., Damodaran, S. (1994): Heat-induced conformational changes in whey protein isolate and its relation to foaming properties. Journal of Agricultural and Food Chemistry 42 (4), 846-855. https://doi.org/10.1021/jf00040a002 